\title{
Identification of Visual Influence Zones of Wind Farms in Lithuania
}

\author{
Jonas Abromas, Jūratė Kamičaitytė-Virbašienė, Kaunas University of Technology
}

\begin{abstract}
Visual impact of wind farms located in Silute and Silale regions is analyzed in the paper. The results of the field survey are compared with the theoretical visual impact zones. The sizes of visual impact zones and degrees of visual impact of wind turbines are established. The main established factors of visual influence of wind farms are forested areas, settlements, relief forms and weather conditions.
\end{abstract}

Keywords - Wind turbines, wind farms, visual impact, zones of visual influence.

Landscape constantly changes because of human activity and this alternation is not always positive. The landscape loses its identity, variety, and scenic beauty - the main values of landscape [5].

Objects of alternative energy have miscellaneous impact on visual environment [4]. Of all the alternative energy facilities, wind turbines are notable for their visual parameters. The height of towers of wind turbines that are currently under construction is $80 \mathrm{~m}-120 \mathrm{~m}$, and the total height is $120 \mathrm{~m}-160 \mathrm{~m}$. Thus wind turbines become dominant verticals in the landscape. Wind turbines can be seen up to $20 \mathrm{~km}-25 \mathrm{~km}$ under ideal weather conditions. When locating such objects in a landscape, it is very important to assess their visual impact on the objects of cultural heritage, recreational zones, protected areas and other visually sensitive objects, and when constructing wind turbines, a special attention has to be paid to the visual impact assessment. Wind turbine often visually influences several visual types of landscape [2]. Visual impact of wind farms is even more significant. Therefore, in order to assess the visual impact properly, it is necessary to determine the area of the landscape which is under visual impact, i.e. it is important to determine the size of visual influence zone and the character of visual impact of wind turbine/ farm in the particular zone.

Visual impact of wind turbines depends on many factors: wind turbine size, its color, form, observation distance, landscape richness, time of the day, and other factors [6]. Their visual contrast with rural landscape can be evaluated positively as well, e.g. the transitioning of tower whiteness into the greenness can visually be in harmony with green agricultural surroundings.

Visual impact of wind farms located in the regions of Silute and Silale is analyzed in the paper. The main aim of the paper is after comparison of the theoretical sizes of visual influence zones and the degrees of visual significance with the results of empirical research, to identify possible ways of elaboration of methodology of visual impact assessment establishing visual influence zones. The main results of the research include established major factors of visual impact of wind farms, sizes of zones of visual influence and character of visual impact in different zones of visual influence.

\section{Methods}

After visual impact zones of wind turbines in different countries have been analyzed and the situation in Lithuania taken into consideration, the table of hypothetical degrees of wind turbine visual impact has been created.

To determine the precision of visual impact degrees, the survey in situ has been conducted, the results of which have later been compared with the theoretical-hypothetical visual impact degrees (a comparative analysis has been done).

The object of the survey is three wind farms located in the West of Lithuania in the regions of Silute and Silale.

Zones of visual influence of the wind farms were evaluated from the selected observation points. The visual influence of the wind farms was evaluated on 27 June 2012, from 10 am to $6 \mathrm{pm}$. The day was sunny, and the visibility of wind turbines was very good.

The two wind farms analyzed are situated near the villages of Vilkyciai, Lankupiai, Ciuteliai and Mockiai in Silute region. The first wind farm consisting of 6 wind turbines was constructed in 2010. The second wind farm consisting of 17 wind turbines was constructed in 2012. The turbines of both wind farms are of the same type - Enercon E-82 (2 MW capacity each). The height of their towers is $85 \mathrm{~m}$, the length of their blades is $34 \mathrm{~m}$, and the total diameter of the set of blades is $82 \mathrm{~m}$; the total height of a wind turbine with one of the blades at the top position is $150 \mathrm{~m}$.

On the territory of the wind farms there is a landscape of littoral plains with slight vertical dispersion. Entirely open agricultural visual spaces prevail. There are several small areas of forest. The distance between the wind turbines and Curonian Lagoon is $7 \mathrm{~km}$. The wind turbines are visible from Curonian Spit and therefore the observation points were selected in Juodkrante and Nida.

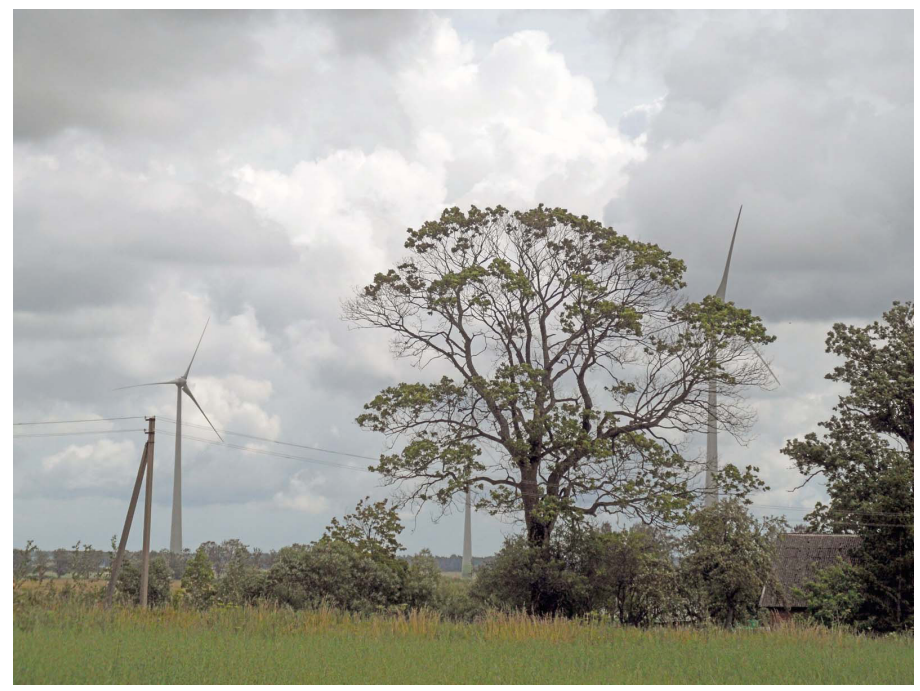

Fig. 1. Photo made from observation point No. 2 - Silute region [9]. 
TABLE I

Theoretical Visual Impact Zones of Wind Turbines [Author of Article and 1, 3, 7].

\begin{tabular}{|c|c|c|}
\hline $\begin{array}{l}\text { Distance to the } \\
\text { wind farm, } \mathrm{km}\end{array}$ & Visual impact degree & $\begin{array}{l}\text { Exposure zones of } \\
\text { anthropogenic elements }\end{array}$ \\
\hline $0-1$ & $\begin{array}{l}\text { Wind turbines dominate because of their large scale, movement of blades, close proximity } \\
\text { and their number. }\end{array}$ & $\begin{array}{l}\text { Scale domination zone (up } \\
\text { to } 500 \mathrm{~m} \text { ) }\end{array}$ \\
\hline $1-3$ & $\begin{array}{l}\text { Wind turbines generally dominate in a landscape. } \\
\text { The impact is more significant due to the proximity of wind turbines, which dominate in a } \\
\text { landscape. }\end{array}$ & $\begin{array}{l}\text { Sight domination zone (up } \\
\text { to } 3.5 \mathrm{~km} \text { ) }\end{array}$ \\
\hline $3-5$ & $\begin{array}{l}\text { Wind turbines are clearly seen, and their impact is average. Also, with the distance their } \\
\text { domination decreases. The blade movement is seen. } \\
\text { Though wind turbines are seen, they are not totally dominating when being observed from the } \\
\text { observation point (with enough level of visibility). They become landscape accents. }\end{array}$ & $\begin{array}{l}\text { Psychological effect zone } \\
\text { (up to } 6.0 \mathrm{~km} \text { ) }\end{array}$ \\
\hline $5-7$ & $\begin{array}{l}\text { Wind turbines are seen but do not stand out clearly from the overall picture. The blade } \\
\text { movement is seen when visibility is good and average. They become landscape accents. }\end{array}$ & $\begin{array}{l}\text { Psychological effect zone } \\
\text { (up to } 6.0 \mathrm{~km} \text { ) }\end{array}$ \\
\hline $7-10$ & $\begin{array}{l}\text { Wind turbines are less clear, and, visually, their size is decreased, but movement can be } \\
\text { noticed (level of subdominants). }\end{array}$ & \multirow{5}{*}{$\begin{array}{l}\text { Object is visible but it } \\
\text { becomes impersonal at the } \\
\text { background of landscape. }\end{array}$} \\
\hline $10-12$ & $\begin{array}{l}\text { The visual impact is weak, and the movement can be noticed on a bright day - wind turbines } \\
\text { get among all the common elements (background elements). }\end{array}$ & \\
\hline $13-17$ & $\begin{array}{l}\text { Wind turbines become indistinct, with slight impact on the remote landscape. } \\
\text { The movement of blades can be seen, but with greater distance they become background } \\
\text { elements. }\end{array}$ & \\
\hline $18-20$ & $\begin{array}{l}\text { Wind turbines and movement of blades can be seen on a bright day but their visual impact is } \\
\text { insignificant. }\end{array}$ & \\
\hline $20+$ & $\begin{array}{l}\text { No impact or it is insignificant. } \\
\text { Wind turbines can be seen but usually they are blurred or indiscernible; also, the relief or } \\
\text { vegetation can worsen the sight. }\end{array}$ & \\
\hline
\end{tabular}

TABLE II

Sizes of Visual Impact Zones and Degrees of Visual Impact of Wind Turbines Established During Empirical Survey.

The First and Second Wind Farms (in Silute Region).

\begin{tabular}{|c|c|c|}
\hline $\begin{array}{l}\text { The number } \\
\text { and location of } \\
\text { observation point }\end{array}$ & $\begin{array}{l}\text { Distance } \\
\text { to wind } \\
\text { turbines, } \mathrm{km}\end{array}$ & Visual impact degree \\
\hline $\begin{array}{l}\text { 1. Village } \\
\text { Lankupiai }\end{array}$ & 1 & $\begin{array}{l}\text { Wind farm consisting of } 6 \text { wind turbines is located in the western part of Lankupiai village, and in the } \\
\text { eastern part there is a wind park consisting of } 17 \text { wind turbines. The distance between the wind turbines } \\
\text { and the village is } 1 \mathrm{~km}-3 \mathrm{~km} \text {. Observing from the selected viewing point, six wind turbines dominate } \\
\text { visually in the visual space. Due to the vegetation situated in front of the wind turbines, the lower part of } \\
\text { their towers cannot be seen. }\end{array}$ \\
\hline $\begin{array}{l}\text { 2. Village } \\
\text { Lankupiai }\end{array}$ & 1 & $\begin{array}{l}\text { Four wind turbines are seen looking to the east. Although the observing distance is } 1 \mathrm{~km} \text {, the wind turbines } \\
\text { lose their dominance in the landscape. This is determined by mature trees existing between the wind } \\
\text { turbines and the observer, which screen the turbines and pylons of air electric line (Fig. 1). }\end{array}$ \\
\hline $\begin{array}{l}\text { 3. Road Priekule- } \\
\text { Kintai }\end{array}$ & 2 & $\begin{array}{l}\text { The observation point is specific because both wind farms can be seen from it in the context of agrarian } \\
\text { landscape. The nearby wood situated in front of the turbines partially screens their towers. Wind turbines } \\
\text { dominate in the landscape. }\end{array}$ \\
\hline $\begin{array}{l}\text { 4. Road Priekule- } \\
\text { Silute }\end{array}$ & 2,5 & $\begin{array}{l}\text { Although a lot of elements of anthropogenic activity can be seen in the visual space (rail roadbed, } \\
\text { electric pylons and lines, road, single structures), the wind turbines obviously dominate in the contextual } \\
\text { environment. }\end{array}$ \\
\hline $\begin{array}{l}\text { 5. Road Priekule- } \\
\text { Kintai }\end{array}$ & 5 & $\begin{array}{l}\text { Agrarian landscape dominates in the viewing field. The wind turbines are seen clearly. The movement } \\
\text { of blades is also seen but partially disappears in the background of clouds. The wind turbines become } \\
\text { landscape accents. }\end{array}$ \\
\hline $\begin{array}{l}\text { 6. Road Klaipeda- } \\
\text { Silute }\end{array}$ & 8,5 & $\begin{array}{l}\text { Due to the nearby wood, half/two thirds of the lower part of turbines towers cannot be seen. Due to the air } \\
\text { electric lines, which are situated near the observer, the wind turbines become subdominants. }\end{array}$ \\
\hline $\begin{array}{l}\text { 7. Village } \\
\text { Juodkrante }\end{array}$ & 15 & $\begin{array}{l}\text { Due to the favorable observing conditions (Curonian Lagoon in front of the observer), the closer wind } \\
\text { farm consisting of } 6 \text { wind turbines becomes a visual accent. The lower part of the towers of turbines is } \\
\text { screened by the wood. The movement of blades is seen. The further wind farm consisting of } 17 \text { wind } \\
\text { turbines (the distance from the observer is } 17 \mathrm{~km}-19 \mathrm{~km} \text { ) cannot be seen clearly (background element). }\end{array}$ \\
\hline $\begin{array}{l}\text { 8. Road Klaipeda- } \\
\text { Silutė (near } \\
\text { Klaipeda city) }\end{array}$ & 19,5 & $\begin{array}{l}\text { The wind turbines are seen from the road Klaipeda-Silute from this observation point. Electric lines, pylons, } \\
\text { and vegetation dominate in the visual space. Due to the observing distance and the mentioned visual obstacles, } \\
\text { visual impact of the turbines becomes insignificant. The movement of blades can be seen partially. }\end{array}$ \\
\hline 9. Village Nida & 28 & The wind turbines are seen but visual impact is insignificant. \\
\hline
\end{tabular}


TABLE III

Sizes of Visual Impact Zones and Degrees of Visual Impact of Wind Turbines Established During Empirical Survey. The Third Wind Farm (in Silale Region).

\begin{tabular}{|c|c|c|}
\hline $\begin{array}{l}\text { The number } \\
\text { and direction of } \\
\text { observation point } \\
\text { on the highway }\end{array}$ & $\begin{array}{l}\text { Distance } \\
\text { to wind } \\
\text { turbines, } \mathrm{km}\end{array}$ & Visual impact degree \\
\hline $\begin{array}{l}\text { 1. The point closest } \\
\text { to the wind farm }\end{array}$ & 0.5 & $\begin{array}{l}\text { As wind turbines are constructed in the higher elevation sites, their dominance in the landscape increases. } \\
\text { The existing vegetation only partially screens the lower parts of the towers. Due to the observation } \\
\text { distance and height of the wind turbines }(150 \mathrm{~m}) \text {, they dominate in the visual space. }\end{array}$ \\
\hline $\begin{array}{l}\text { 2. Going in the } \\
\text { direction of Vilnius }\end{array}$ & 1.5 & $\begin{array}{l}\text { Due to the nearby wood, half/two thirds of the lower part of turbines towers cannot be seen, and the } \\
\text { dominance of the turbines decreases. }\end{array}$ \\
\hline $\begin{array}{l}\text { 3. Going in the } \\
\text { direction of Vilnius }\end{array}$ & 4 & $\begin{array}{l}\text { Due to the dense wood, only the sets of blades of the wind turbines are seen. The movement of blades is } \\
\text { seen clearly. The wind turbines become landscape accents. }\end{array}$ \\
\hline $\begin{array}{l}\text { 4. Going in the } \\
\text { direction of Vilnius }\end{array}$ & 5.5 & $\begin{array}{l}\text { Due to the nearby wood and observation point situated in the higher elevation site, one third of the lower } \\
\text { part of turbines towers cannot be seen but wind turbines dominate in the landscape. }\end{array}$ \\
\hline $\begin{array}{l}\text { 5. Going in the } \\
\text { direction of Vilnius }\end{array}$ & 6 & $\begin{array}{l}\text { The wind turbines are seen from the road Klaipeda - Vilnius from this observation point. Due to the hilly } \\
\text { terrain and woods, only the set of blades of one wind turbine and parts of blades of the other turbines are } \\
\text { seen. }\end{array}$ \\
\hline $\begin{array}{l}\text { 6. Going in the } \\
\text { direction of } \\
\text { Klaipeda }\end{array}$ & 2 & $\begin{array}{l}\text { The roadbed screens the towers of wind turbines. Only the lower part of the tower of the closest turbine } \\
\text { is screened and only the sets of blades of the further ones are seen. }\end{array}$ \\
\hline $\begin{array}{l}\text { 7. Going in the } \\
\text { direction of } \\
\text { Klaipeda }\end{array}$ & 4.5 & $\begin{array}{l}\text { Different location of the observed turbines, vegetation, hills, bend of the highway, moving cars do not let } \\
\text { all the turbines dominate. The wind turbine on the hill dominates and the rest of them become landscape } \\
\text { accents (Fig. 1). }\end{array}$ \\
\hline $\begin{array}{l}\text { 8. Going in the } \\
\text { direction of } \\
\text { Klaipeda }\end{array}$ & 5 & $\begin{array}{l}\text { The towers of wind farms are screened by woods and advertising stands. The wind turbines become } \\
\text { landscape accents. }\end{array}$ \\
\hline $\begin{array}{l}\text { 9. Going in the } \\
\text { direction of } \\
\text { Klaipeda }\end{array}$ & 14 & $\begin{array}{l}\text { The movement of blades is seen but the wind turbines are not visually clear. They become background } \\
\text { elements. }\end{array}$ \\
\hline
\end{tabular}

The third wind farm is situated near the village of Stungaiciai in Silale region. It was constructed in 2012. There are 6 wind turbines (the type - Siemens SWT-2.3-101). The height of their towers is $99.5 \mathrm{~m}$, the total diameter of the set of blades is 101 $\mathrm{m}$, and the total height of a wind turbine with one of the blades at the top position is $150 \mathrm{~m}$. Capacity of one wind turbine is 2.3 MW. This is the first wind farm built not in the littoral zone. The distance from the Baltic Sea is $60 \mathrm{~km}$. This wind farm is situated near highway A1 Vilnius - Klaipeda. Considering this, the observation points were located on this highway.

On the territory of the wind farms there is a landscape with middle vertical dispersion (hilly and sloppy landscape with complexes of three-level videotops). Half-open agricultural visual spaces of moraine hills prevail.

\section{RESULTS}

The research results are presented in Tables I, II and III.

\section{Discussion}

After accomplishing the field survey and structuring the data, the zones of visual influence were revised. The following intervals of zones of visual influence are recommended: $0 \mathrm{~km}-$ $1 \mathrm{~km} ; 1 \mathrm{~km}-3 \mathrm{~km} ; 3 \mathrm{~km}-5 \mathrm{~km} ; 5 \mathrm{~km}-7 \mathrm{~km} ; 7 \mathrm{~km}-10 \mathrm{~km}$; $10 \mathrm{~km}-13 \mathrm{~km} ; 13 \mathrm{~km}-16 \mathrm{~km} ; 16 \mathrm{~km}-20 \mathrm{~km} ;>20 \mathrm{~km}$. At a distance of $0 \mathrm{~km}-3 \mathrm{~km}$, wind turbines usually dominate in the landscape, at a distance of $4 \mathrm{~km}-7 \mathrm{~km}$ they become accents, at a distance of $8 \mathrm{~km}-10 \mathrm{~km}$ - subdominants and at a distance of $>10 \mathrm{~km}$ - background elements.

The wood near the observation point significantly affects the visual impact of the wind farm. This aspect was noticed evaluating visual influence of all wind farms analyzed.

Atmospheric conditions such as cloudiness also have a big influence on the visual impact of the wind farm. This aspect was noticed evaluating visual impact of the wind farm (Silute region) from the observation point No. 6. The color of the wind turbines is light grey. When clouds are of the same or similar color, the set of blades in some cases can be invisible or on the contrary can be

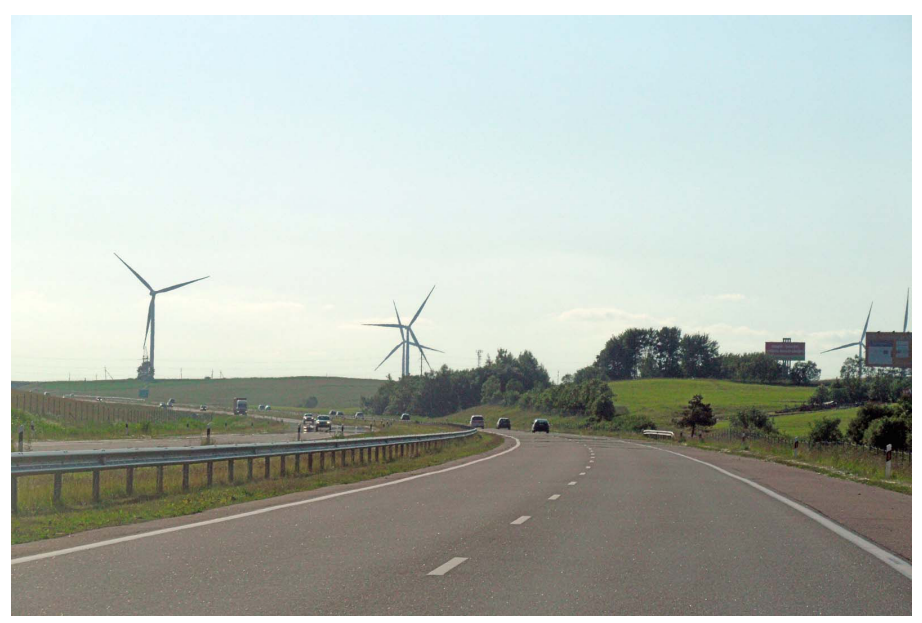

Fig. 2. Photo made from observation points No. 7 - Silale region [9]. 
visible more clearly if the clouds are darker.

The more anthropogenic objects are in the visual space, the more the visual impact of the wind farm is decreased. In some cases a wind farm can become a background element.

Evaluating the visual impact in Silute region, it has been noticed that the wind turbines are constructed very close to the settlements of Vilkyciai and Lankupiai. Considering this aspect, two observing points (No. 1 and 2) were selected in Lankupiai village. There is a wind farm from 6 turbines to the south west from the village and a wind farm from 17 turbines to the east. The distance between the turbines and the village is $1 \mathrm{~km}-3 \mathrm{~km}$. The wind turbines clearly dominate in the contextual landscape and are seen from many sites in the village.

Evaluating the visual impact of wind turbines from Curonian Spit, the visual impact of them is enhanced by Curonian Lagoon situated between the observer and such visual obstacles as water body, which forms the basis of the visual space.

Evaluating the visual impact of wind turbines in Silale region, visibility of the turbines was conditioned by the additional factorterrain undulations. Due to this aspect (as well as forested areas), going by highway in the direction of Vilnius wind turbines become visible only at $6 \mathrm{~km}$ distance.

\section{Conclusions}

1. Due to the height of wind turbines $(150 \mathrm{~m})$, the following objects become dominating visual landmarks in the contextual landscape. Under ideal weather conditions the wind farms can be seen at a distance of $20 \mathrm{~km}-25 \mathrm{~km}$. But there also could be exceptions. The wind farm from Nida settlement is seen at a distance of $28 \mathrm{~km}$. Before carrying out visual impact assessment on site, the analysis of cartographical material should be done. If the territory under visual influence of a wind farm is visually sensitive (there are settlements, objects of interest, main roads, etc.), several observation points have to be selected in a particular zone of visual influence and visual impact from them has to be evaluated.

2. Considering the significance of visual impact of wind turbines, they have to be grouped into separate farms, laid out in the places aloof from residential areas, important territories under protection, as well as recreational zones.

3. Taking into account the specifics of morphological forms of the Lithuanian terrain, it can be stated that undulating relief forms determine more fragmentary visibility of wind turbines and due to this visual impact in some cases decreases and in some cases on the contrary is enhanced because of the position of the observation point and the observed wind turbines (e.g., on top of the hill).

4. It was also noticed that forests, buildings and other vertical objects that are located near the observation point considerably change the visual impact significance. The wind turbines lose their dominance in the landscape and significance of visual impact can be decreased even from the level of dominants to the level of subdominants. Weather conditions have significant influence as well, especially on the visibility of a wind turbine wheel.

\section{REFERENCES}

1. Bučas, J. Karštotvarkos pagrindai. Kaunas: Technology, 2001, p. 282.

2. Domingo-Santos, J. M., de Villarįn, R. F., Rapp-Arrarįs, K., CorralPazos de Provens, E. The visual exposure in forest and rural landscapes: An algorithm and a GIS tool. Landscape and Urban Planning. 2011, vol. 101, No. 1, pp. 52-58. http://dx.doi.org/10.1016/j.landurbplan.2010.11.018

3. Homewood, A. Eden Wind Farm. Landscape and visual impact assessment [online]. Australia, 2011, p. 54. Available from: http://www.epuron.com. au/wp-content/uploads/2012/02/dt_intfc4ef928e173cce_4f2b6df9a0a45. pdf?1Eden_WF_SEE_010811_Appendix\%201_Landscape_Visua1\%20 Impact\%20Assessment\%20V2\%202.pdf

4. Jallouli, J., Moreau, G. An immersive path-based study of wind turbine landscape: A French case in Plouguin. Denmark. Renewable Energy. 2009, vol. 34, no. 3, pp. 597-607. http://dx.doi.org/10.1016/j.renene.2008.05.036

5. Kamičaitytè-Virbašienė, J. Landscape visual quality, the importance and problems of its regulation. Town Planning and Architecture. 2001, No. 4, pp. 202-209.

6. Tsoutsos, T., Tsouchlaraki, A., Tsiropoulos, M., Serpetsidakis, M. Visual impact evaluation of a wind park in a Greek island. Denmark, Applied Energy. 2009, vol. 86, No. 4, pp. 546-553. http://dx.doi.org/10.1016/j. apenergy.2008.08.013

7. University of Newcastle. Visual Assessment of Windfarms : Best Practice. Scottish Natural Heritage Commissioned Report F01AA303A, 2002, p. 79.

8. Photo by Jonas Abromas, 2012.

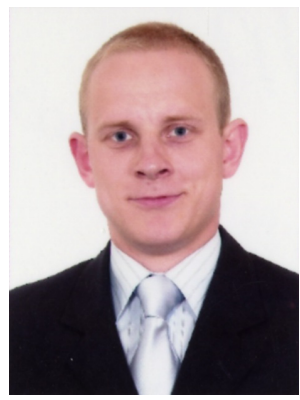

Jonas Abromas. Lecturer, Department of Landscape Architecture and Environmental Design, Klaipeda University. Doctoral student, Kaunas Technological University.

Research Institute of Maritime and Cultural Landscape, Klaipeda University. Scientific interests: recreational architecture, alternative energy, visual impact on the landscape. Teaching interests: landscape architecture, territory planning.

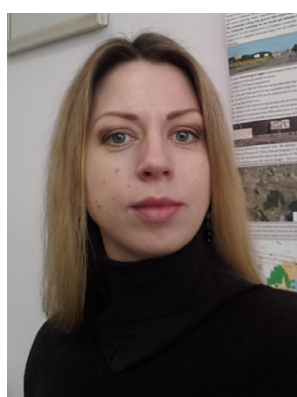

Jūratė Kamičaitytè-Virbašienè. Assoc. Prof., Kaunas University of Technology, Department of Architecture and Land Management. Research interests: landscape visual quality analysis, evaluation and regulation by means of environmental design, methods of planned activity or object visual impact assessment, analysis of social preferences in evaluating visual quality of a landscape and the use of the analysis results in territory planning.

\section{Contact Data}

Jonas Abromas

Kaunas University of Technology, Faculty of Civil Engineering and Architecture Studentu Str. 48, LT-51367 Kaunas, Lithuania

Klaipeda University, Faculty of Natural Science and Mathematics

H. Manto Str. 84, LT-92294 Klaipeda, Lithuania

E-mail: jonasabromas@yahoo.com

Jūratė Kamičaitytè-Virbašienè

Kaunas University of Technology, Faculty of Civil Engineering and Architecture Studentu Str. 48, LT-51367 Kaunas, Lithuania

E-mail: jurate.kamicaityte@ktu.lt 